\title{
Synthesis and Study of Some fused Substituted 1,3,4-Thiadiazoles and 1,2,4- Triazoles from 4-Chloro- phenoxy acetic acid and 2,4-dichlorophenoxy acetic acid
}

\author{
Mudhar A. Othman
}

\begin{abstract}
Department of Chemistry, College of Education for girls, University of Mosul, Mosul, Iraq
E-mail: mudr1973@yahoo.com
\end{abstract}

(Received December 09, 2013; Accepted May 08, 2014; Available online September 01, 2020)

DOI: 10.33899/edusj.2020.166251, (C) 2020, College of Education for Pure Science, University of Mosul. This is an open access article under the CC BY 4.0 license (http://creativecommons.org/licenses/by/4.0/).

\begin{abstract}
:
In this work the synthesis of some substituted 1,2,4-triazoles and five ring system's reported. 2-(4Chlorophenoxy) acetic acid $\left(\mathrm{S}_{1}\right)$ was synthesis from corresponding substituted phenol by its reaction with chloroacetic acid in sodium hydroxide solution, the acids $\left(\mathrm{Q}_{1}\right.$ and $\left.\mathrm{S}_{1}\right)$ esterified with methanol and sulfuric acid to give esters $\left(\mathrm{Q}_{2}\right.$ and $\left.\mathrm{S}_{2}\right)$ which converted to acid hydrazides $\left(\mathrm{Q}_{3}\right.$ and $\left.\mathrm{S}_{3}\right)$ by their reaction with hydrazine hydrate in ethanol.

The acid hydrazides $\left(\mathrm{Q}_{3}\right.$ and $\left.\mathrm{S}_{3}\right)$ were treated with carbon disulfide in potassium hydroxide solution to give potassium salts $\left(\mathrm{Q}_{4}\right.$ and $\left.\mathrm{S}_{4}\right)$ the formed salts were treated with hydrazine hydrate to give substituted 4-amino-1,2,4-triazoles $\left(\mathrm{Q}_{5}\right.$ and $\left.\mathrm{S}_{5}\right)$.

4-Amino-1,2,4-Triazole ( $\mathrm{Q}_{5}$ and $\left.\mathrm{S}_{5}\right)$ were converted to $\left(\mathrm{Q}_{6}\right.$ and $\left.\mathrm{S}_{6}\right), \quad\left(\mathrm{Q}_{9}\right.$ and $\left.\mathrm{S}_{9}\right)$ and $\left(\mathrm{Q}_{10}\right.$ and $\left.\mathrm{S}_{10}\right)$ by treating with $\mathrm{CS}_{2}$ in pyridine, urea and chloroacetic acid. While reaction of 4-amino-1,2,4triazole $\left(Q_{5}\right.$ and $\left.S_{5}\right)$ with phenyl isothiocyanate gave thiosemicarbazide derivatives $\left(Q_{7}\right.$ and $\left.S_{7}\right)$ that converted to $N$-phenyl substituted 1,2,4-triazole $\left(\mathrm{Q}_{8}\right.$ and $\left.\mathrm{S}_{8}\right)$.
\end{abstract}

The structures of the synthesized compounds were confirmed by physical and spectral data.

Keywords: Thiosemicarbazide, 1,3,4-Oxadiazole, 1,3,4-Thiadiazole, 1,2,4-Triazole.

$$
\begin{aligned}
& \text { تحضير ودراسة بعض المعوضات الملتحمة ل1،3،4-ثيادايازول و 1،2،4-ترايازول من 4-كلورو-فينوكسي } \\
& \text { حامض الأسيتيك و 2،2-ثائي كلورو فينوكسي حامض الأسيتيك. } \\
& \text { مضر أكرم عثمان } \\
& \text { قسم الكيمياء، كلية التربية للبنات، جامعة الموصل، الموصل، العراق }
\end{aligned}
$$

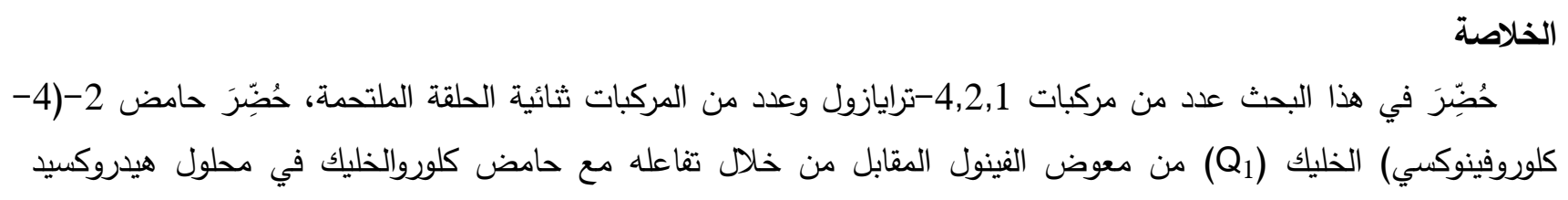




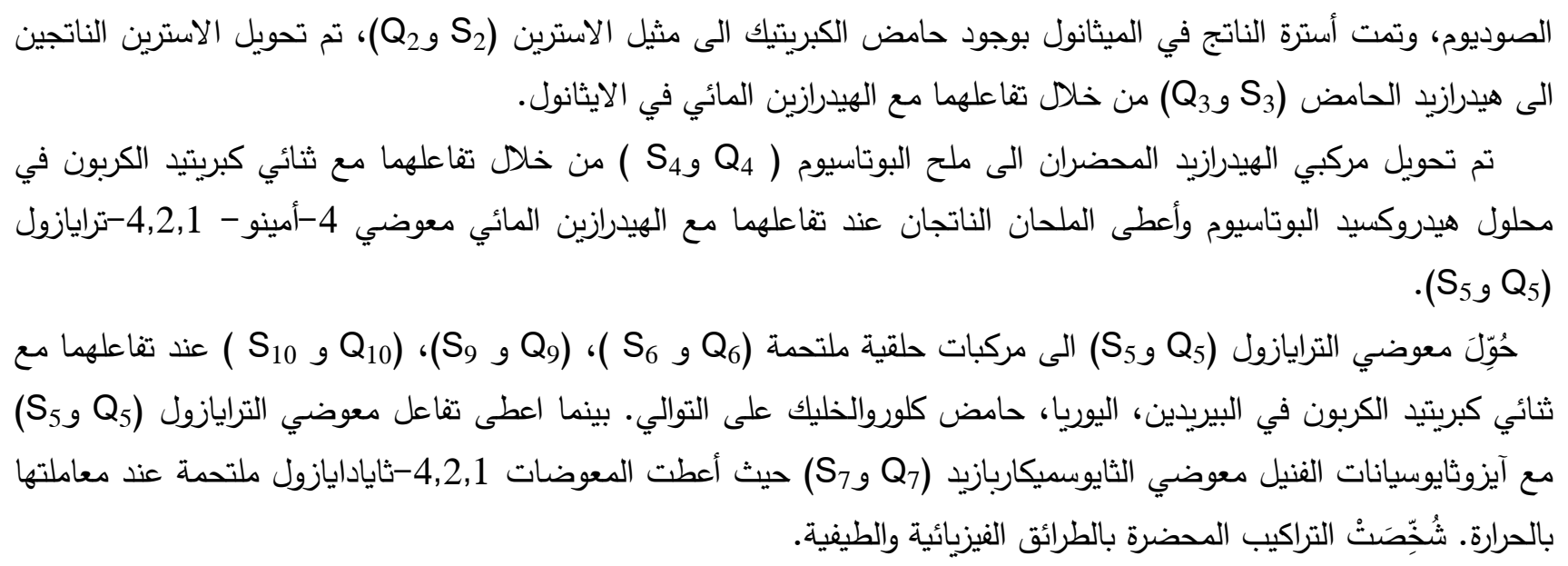

\section{Introduction:}

In the last few decades, the chemistry of heterocycles containing 1,2,4-triazole moiety was reported to show a wide spectrum of biological activity as antibacterial, against B. subtilis, $S$. aureus, $P$. aeruginosa and E. coli. [1,2] like compound (I) that prepared by reaction of $N$-acetyl-p-amino benzoic acid and 4-amino-5-phenyl-4H-1,2,4-triazole-3-thiol in $\mathrm{POCl}_{3}$.

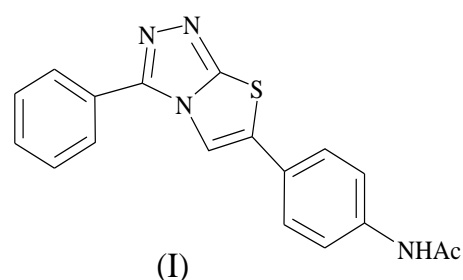

(I)

1,2,4-Triazole derivatives are showing very promising and excellent therapeutic effectiveness[3]. Furthermore synthesis of 6-(4-substituted phenyl)-8-(N-substituted phenyl)-3-(pyridinyl) [1,2,4] triazolo $[3,4-\mathrm{b}][1,3,4]$ thiadiazepine (II) by reaction of 4-amino-5-pyridin-3-yl-4H-1,2,4-triazole-3thiol with chalcone in ethanol[4].<smiles>[R]c1ccc(C2=CC(c3ccc([R1])cc3)=Nn3c(nnc3-c3cccnc3)S2)cc1</smiles>

The reaction of potassium-3-(4-nitrobenzoyl) dithiocarbazate with hydrazine hydrate give 4amino-3-mercapto-5-(4-nitro)phenyl-1,2,4-triazole that used as a nucleus to prepared 4-(substituted ethanoyl) amino-3-mercapto-5-(4-nitro) phenyl-1,2,4-triazoles were synthesized as novel antimicrobial agents starting from 4-nitrobenzoic acid[5].

Condensation of substituted 1,2,4-triazole and isoniazide gives $N$-[(3,5-substituted)-4H-1,2,4triazole-4yl] isonicotinamide show in-vitro antimicrobial activity [6,7]. 
In another search 4-amino-5-(4-chlorophenyl)-4H-1,2,4-triazole-3-thiol was prepared by reacting of 4-chlorobenzoic acid with carbohydrazide[8]. While Liu[9], et al were prepared substituted 1,2,4triazole by reacting of thioacetohydrazide-5,7-dimethyl-1,2,4-triazolo[1,5-a]pyrimidine potassium hydroxide in carbon disulfide (III).<smiles>Cc1ccn2nc(SCc3nnc(S)n3N)nc2n1</smiles>

(III)

The substituted 1,2,4-triazole show antianxietic [10] and antifungal activities[11,12].

Fused substituted 1,3,4-thiadiazole was prepared by dehydration of 1-(4-hydroxy-2phenylthiazol-3(2H)-yl) isothiourea show antitubercular[13]. Due to the presence of bromophenyl group 1,3,4-thiadiazole with show antiviral activity as compound $[14,15]$.

Novel bicyclic and tricyclic substituted 1,3,4-thiadiazole was prepared by Beresneva T. and Abele E.[16] and the used sodium bromide and acetic acid with 1,3-dichloroacetone produced substituted 1,3,4-thiadiazole like compound under Mannich reaction conditions[17].

\section{Experimental:}

a. Measurements:

Melting points were determined in open capillary tubes in a Thomas Hoover melting point apparatus and are uncorrected .

UV-Visible/Shimadzu-1601 and Infrared spectra were recorded on FT-IR, Shimadzu/157.

\section{b. Preparations:}

2-(4-chlorophenoxy)acetic acid $\left(Q_{1}\right)[18]$ :

A solution of sodium hydroxide $(4.5 \mathrm{~g} / 25 \mathrm{ml})$ was added slowly to mixture of 4-chlorophenol (6.63 g, 0.049 mole) and chloroacetic acid ( $4.7 \mathrm{~g}, 0.049$ mole). The mixture was heated with stirring for (30 minutes) to evaporate most of the solvent, then water $(150 \mathrm{ml})$ was added and the solution acidified with concentrated hydrochloric acid. The resultant precipitate was filtered and recrystallized from ethanol / water. m.p. $154-155^{\circ} \mathrm{C}$ (Lit. $154-155^{\circ} \mathrm{C}$ ) yield \% (65\%).

\section{Methyl-2-( substituted phenoxy)acetate $\left(Q_{2}, S_{2}\right)[19]$ :}

In $(250 \mathrm{ml})$ dry round bottom flask, a mixture of $\left(\mathrm{Q}_{1}\right.$ or $\left.\mathrm{S}_{1}\right)(0.001 \mathrm{~mol})$ and absolute methanol $(50 \mathrm{ml})$ were taken. Few drops of conc. Sulfuric acid along with a small porcelain chip were added. The reaction mixture was refluxed for (10 hours) on heating mantle, the mixture then cooled in an ice-bath, added $10 \%$ sodium bicarbonate $(5 \mathrm{ml})$. Filtrated by buchner funnel, washed with cold water three times, then oily products were extract with diethylether . b.p. (Lit. [15] $\left.300.5^{\circ} \mathrm{C}\right)$. Tables $(1,2,3$ and 4).

\section{2-(Substituted phenoxy) acetohydrazide $\left(Q_{3}, S_{3}\right)[20]$.}

A mixture of methyl ester $\left(\mathrm{Q}_{2}\right.$ or $\left.\mathrm{S}_{2}\right)(2.81 \mathrm{~g}, 0.01 \mathrm{~mole})$ and hydrazine hydrate $(95 \%, 2.5 \mathrm{ml}, 0.05$ mole) in $(50 \mathrm{ml})$ absolute ethanol was refluxed for (3 hours). The mixture was cooled to room temperature then the solvent evaporate under reduced pressure. The precipitate was filtered and recrystallized from ethanol. Tables (1,2,3 and 4).

Potassium salt of thiosemicarbazide derivatives $\left(Q_{4}, S_{4}\right)[21]$

To a cold solution of $\left(\mathrm{Q}_{3}, \mathrm{~S}_{3}\right)(0.01 \mathrm{~mol})$ in ethanol $(25 \mathrm{ml})$ and potassium hydroxide $(0.84 \mathrm{~g}$, $0.015 \mathrm{~mol})$, carbon disulfide $(1.14 \mathrm{~g}, 0.015 \mathrm{~mol})$ was added. The reaction mixture was stirred at room temperature for ( 8 hours), and the precipitate formed was collected by filtration and washed with dry diethyl ether to give yellow solid of potassium salts $\left(\mathrm{Q}_{4}, \mathrm{~S}_{4}\right)$. Tables $(1,2,3$ and 4$)$. 


\section{4-Amino-5-( substituted phenoxymethyl)-4H-1, 2, 4-triazole-3-thiol $\left(Q_{5}, S_{5}\right)[22]$}

To compounds $\left(\mathrm{Q}_{4}, \mathrm{~S}_{4}\right)$ hydrazine hydrate solution $(10 \mathrm{ml}, 0.2 \mathrm{ml})$ was added and the contents of the round-bottom flask are refluxed for about one hour. The change in the color of the reaction mixture to one of the degrees of green with the release of hydrogen sulfide gas coincides with obtaining a homogeneous mass of solution. Then the mixture was cooled and diluted by adding $(100 \mathrm{ml})$ cold water in batches. The cold mixture was acidified by adding concentrated hydrochloric acid. The solid separated from the solution was filtered, washed with water several times, allowed to dry and recrystallized it from methanol. Tables (1,2,3 and 4).

\section{3-( Substituted phenoxymethyl)-[1,2,4]triazolo[3,4-b][1,3,4] thiadiazolo-6(5H)-thione $\left(Q_{6}, S_{6}\right)[23]$}

A mixture of compounds $\left(\mathrm{Q}_{5}\right.$ or $\left.\mathrm{S}_{5}\right)(0.01 \mathrm{~mol})$, dry pyridine $(20 \mathrm{ml})$ and carbon disulphide $(0.01$ mol), wasrefluxed for (3 hour). The mixture was cooled and poured into a beaker containing ice-water. A solid product $\left(\mathrm{Q}_{6}\right.$ or $\left.\mathrm{S}_{6}\right)$ was obtained by filtering the and purifyied by recrystallized it from ethanol. Tables (1,2,3 and 4).

2-\{[4-amino-5-( substituted phenoxymethyl)-4H-1, 2, 4-triazole-3-yl]thio\}-N-phenyl hydrazine carbothio amide $\left(Q_{7}, S_{7}\right)[19]$ :

product was filtered and purified by recrystallized from ethanol.

A mixture of $\left(\mathrm{Q}_{5}\right.$ or $\left.\mathrm{S}_{5}\right)(0.1 \mathrm{~mol})$, phenyl isothiocyanate $(0.1 \mathrm{~mol})$ and powdered of sodium hydroxide $(0.8 \mathrm{~g})$ dissolved in DMF $(25 \mathrm{ml})$ was continuous stirred at room temperature for (24 hours). The product was poured into dilute acetic acid $(5 \%, 15 \mathrm{ml})$. The precipitated product was filtered, leave at room temperature to dry and purified by recrystallized it from $96 \%$ ethanol. $N$-phenyl-3-( substituted phenoxymethyl)-[1,2,4] triazolo [3,4-b][1,3,4] thiadiazol-6-amine $\left(Q_{8}, S_{8}\right)$ [19]:

Thiosemicarbazide $\left(\mathrm{Q}_{7}, \mathrm{~S}_{7}\right)$ derivative was fused in an oil-bath above its melting point. The products was cooled, diluted with ethyl acetate, and filtered. The solid products was purified by recrystallization from ethanol. Tables (1,2,3 and 4).

3-( Substituted phenoxymethyl)-[1,2,4]triazolo[3,4-b][1,3,4] thiadiazolo-6(5H)-one $\left(Q_{9,} S_{9}\right)[19]$ :

A mixture of $\left(Q_{5}\right.$ or $\left.\mathrm{S}_{5}\right)(0.01 \mathrm{~mol})$ and urea $(0.13 \mathrm{~mol})$ was heated at $\left(180-190{ }^{\circ} \mathrm{C}\right)$ on sand bath for (6 hours). The reaction mixture were cooled and added to a solution of sodium hydroxide (5\%, 20 $\mathrm{ml})$, then filtered and the filtrate acidified with dilute hydrochloric acid. The solid product $\left(\mathrm{Q}_{9}\right.$ or $\left.\mathrm{S}_{9}\right)$ was purified by recrystallization from ethanol. Tables (1,2,3 and 4).

\section{3-(Substituted phenoxymethyl)-5H-[1,2,4]triazolo[3,4-b][1,3,4] thiadiazin-6(7H)-one $\left(Q_{10}\right.$ and $\left.S_{10}\right)$} [19]:

A mixture of $\left(\mathrm{Q}_{5}\right.$ or $\left.\mathrm{S}_{5}\right)(0.01 \mathrm{~mol})$, chloroacetic acid $(0.94 \mathrm{~g}, 0.01 \mathrm{~mol})$ and anhydrous sodium acetate $(0.82 \mathrm{~g}, 0.01 \mathrm{~mol})$ in absolute alcohol $(50 \mathrm{ml})$ was heated under reflux for (6 hours) and then cooled in ice. The solid thus separated were filtered, washed thoroughly with water and crystallized from methanol. Tables (1,2,3 and 4). 
Table 1: physical data of compounds $\left(\mathrm{Q}_{3}-\mathrm{Q}_{10}\right)$

\begin{tabular}{|c|c|c|c|c|}
\hline Comp. No. & m.p. ${ }^{\circ} \mathrm{C}$ & Yield $\%$ & Color & Molecular Formula \\
\hline $\mathrm{Q}_{1}$ & $154-155$ & 63 & white & $\mathrm{C}_{8} \mathrm{H}_{7} \mathrm{ClO}_{3}$ \\
\hline $\mathrm{Q}_{2}$ & oily & 87 & brown & $\mathrm{C}_{9} \mathrm{H}_{9} \mathrm{ClO}_{3}$ \\
\hline $\mathrm{Q}_{3}$ & $153-155$ & 90 & white & $\mathrm{C}_{8} \mathrm{H}_{9} \mathrm{ClN}_{2} \mathrm{O}_{2}$ \\
\hline $\mathrm{Q}_{4}$ & $270-275$ & 86 & Dark brown & $\mathrm{C}_{9} \mathrm{H}_{8} \mathrm{ClKN}_{2} \mathrm{O}_{2} \mathrm{~S}_{2}$ \\
\hline $\mathrm{Q}_{5}$ & $116-118$ & 85 & Pale brown & $\mathrm{C}_{9} \mathrm{H}_{9} \mathrm{ClN}_{4} \mathrm{OS}$ \\
\hline $\mathrm{Q}_{6}$ & $146-148$ & 18 & white & $\mathrm{C}_{10} \mathrm{H}_{7} \mathrm{ClN}_{4} \mathrm{OS}_{2}$ \\
\hline $\mathrm{Q}_{7}$ & $118-120$ & 60 & Brown & $\mathrm{C}_{16} \mathrm{H}_{16} \mathrm{ClN}_{7} \mathrm{OS}_{2}$ \\
\hline $\mathrm{Q}_{8}$ & $180-182$ & 87 & Pale brown & $\mathrm{C}_{16} \mathrm{H}_{12} \mathrm{ClN}_{5} \mathrm{OS}$ \\
\hline $\mathrm{Q}_{9}$ & $150-152$ & 43 & White & $\mathrm{C}_{10} \mathrm{H}_{7} \mathrm{ClN}_{4} \mathrm{O}_{2} \mathrm{~S}$ \\
\hline $\mathrm{Q}_{10}$ & $120-122$ & 16 & Pale brown & $\mathrm{C}_{11} \mathrm{H}_{9} \mathrm{ClN}_{4} \mathrm{O}_{2} \mathrm{~S}$ \\
\hline
\end{tabular}

Table 2: physical data of compounds $\left(\mathrm{S}_{3}-\mathrm{S}_{10}\right)$

\begin{tabular}{|c|c|c|c|c|}
\hline Comp. No. & m.p. ${ }^{\circ} \mathrm{C}$ & Yield \% & Color & Molecular Formula \\
\hline $\mathrm{S}_{1}$ & \multicolumn{4}{|c|}{ Ready-made } \\
\hline $\mathrm{S}_{2}$ & oily & 65 & colorless & $\mathrm{C}_{9} \mathrm{H}_{8} \mathrm{Cl}_{2} \mathrm{O}_{3}$ \\
\hline $\mathrm{S}_{3}$ & $152-154$ & 54 & White & $\mathrm{C}_{8} \mathrm{H}_{8} \mathrm{Cl}_{2} \mathrm{~N}_{2} \mathrm{O}_{2}$ \\
\hline $\mathrm{S}_{4}$ & 320 dec. & 95 & White & $\mathrm{C}_{9} \mathrm{H}_{7} \mathrm{Cl}_{2} \mathrm{KN}_{2} \mathrm{O}_{2} \mathrm{~S}_{2}$ \\
\hline $\mathrm{S}_{5}$ & 146-148 & 35 & Pale brown & $\mathrm{C}_{9} \mathrm{H}_{8} \mathrm{Cl}_{2} \mathrm{~N}_{4} \mathrm{OS}$ \\
\hline $\mathrm{S}_{6}$ & $168-170$ & 14 & Grey & $\mathrm{C}_{10} \mathrm{H}_{6} \mathrm{Cl}_{2} \mathrm{~N}_{4} \mathrm{OS}_{2}$ \\
\hline $\mathrm{S}_{7}$ & 156-158 & 55 & Grey & $\mathrm{C}_{16} \mathrm{H}_{15} \mathrm{Cl}_{2} \mathrm{~N}_{7} \mathrm{OS}_{2}$ \\
\hline $\mathrm{S}_{8}$ & $158-160$ & 53 & white & $\mathrm{C}_{16} \mathrm{H}_{11} \mathrm{Cl}_{2} \mathrm{~N}_{5} \mathrm{OS}$ \\
\hline $\mathrm{S}_{9}$ & $156-158$ & 10 & Dark brown & $\mathrm{C}_{10} \mathrm{H}_{6} \mathrm{Cl}_{2} \mathrm{~N}_{4} \mathrm{O}_{2} \mathrm{~S}$ \\
\hline $\mathrm{S}_{10}$ & $118-120$ & 21 & Pale yellow & $\mathrm{C}_{11} \mathrm{H}_{8} \mathrm{Cl}_{2} \mathrm{~N}_{4} \mathrm{O}_{2} \mathrm{~S}$ \\
\hline
\end{tabular}

Table 3: Ultra Violet and Infrared spectrum data of compounds $\left(\mathrm{Q}_{3}-\mathrm{Q}_{10}\right)$

\begin{tabular}{|c|c|c|c|c|c|c|c|c|c|c|}
\hline & & \multicolumn{10}{|c|}{$v \mathrm{~cm}^{-1}$} \\
\cline { 3 - 12 } $\begin{array}{c}\text { Comp. } \\
\text { No. }\end{array}$ & $\begin{array}{c}\mathrm{U} . \mathrm{V} \lambda \\
\text { max. }\end{array}$ & $\begin{array}{c}\mathrm{C}=\mathrm{C} \\
\text { arom } \\
\text { atic }\end{array}$ & $\begin{array}{c}\mathrm{C}-\mathrm{Cl} \\
\text { arom } \\
\text { atic }\end{array}$ & $\mathrm{N}-\mathrm{H}$ & $\begin{array}{l}\| \\
\mathrm{C}-\mathrm{N}\end{array}$ & $\begin{array}{l}\| \\
\mathrm{C}-\mathrm{O}\end{array}$ & $\mathrm{C}=\mathrm{N}$ & $\mathrm{C}=\mathrm{S}$ & $\mathrm{C}-\mathrm{S}-\mathrm{C}$ & $\mathrm{C}-\mathrm{O}-\mathrm{C}$ \\
\hline $\mathrm{Q}_{1}$ & 236 & 1583 & 707 & --- & --- & 1707 & --- & --- & 645 & 1104 \\
\hline 2 & 256 & 1595 & 722 & --- & --- & 1760 & --- & --- & 642 & 1129 \\
\hline $\mathrm{Q}_{3}$ & 285 & 1541 & 798 & 3310 & 1671 & --- & --- & --- & 592 & 1071 \\
\hline $\mathrm{Q}_{4}$ & 290 & 1493 & 708 & 3419 & 1663 & --- & --- & 1252 & 665 & 1054 \\
\hline $\mathrm{Q}_{5}$ & 294 & 1589 & 732 & 3442 & --- & --- & 1667 & 1249 & 675 & 1022 \\
\hline $\mathrm{Q}_{6}$ & 312 & 1522 & 699 & 3447 & --- & --- & 1660 & 1242 & 635 & 1076 \\
\hline $\mathrm{Q}_{7}$ & 299 & 1549 & 695 & 3312 & --- & --- & 1682 & 1240 & 631 & 1095 \\
\hline $\mathrm{Q}_{8}$ & 305 & 1552 & 741 & 3436 & --- & --- & 1604 & --- & 683 & 1087 \\
\hline $\mathrm{Q}_{9}$ & 317 & 1579 & 699 & 3160 & 1618 & --- & 1618 & --- & 617 & 1061 \\
\hline $\mathrm{Q}_{10}$ & 314 & 1556 & 736 & 3444 & 1667 & --- & 1660 & --- & 606 & 1024 \\
\hline
\end{tabular}


Table 4: Ultra Violet and Infrared spectrum data of compounds $\left(\mathrm{S}_{3}-\mathrm{S}_{10}\right)$

\begin{tabular}{|c|c|c|c|c|c|c|c|c|c|c|}
\hline \multirow{2}{*}{$\begin{array}{c}\text { Comp. } \\
\text { No. }\end{array}$} & $\begin{array}{c}\mathrm{U} . \mathrm{V} \\
\text { max. }\end{array}$ & $\begin{array}{c}\mathrm{C}=\mathrm{C} \\
\text { aromatic }\end{array}$ & $\begin{array}{c}\mathrm{C}-\mathrm{Cl} \\
\text { aromatic }\end{array}$ & $\mathrm{N}-\mathrm{H}$ & $\begin{array}{l}\mathrm{O} \\
\mathrm{C}-\mathrm{N}\end{array}$ & $\begin{array}{l}\| \text { C- } \\
\mathrm{C}-\mathrm{O}\end{array}$ & $\mathrm{C}=\mathrm{N}$ & $\mathrm{C}=\mathrm{S}$ & $\begin{array}{c}\mathrm{C}-\mathrm{S}- \\
\mathrm{C}\end{array}$ & $\begin{array}{c}\text { C-O- } \\
\mathrm{C}\end{array}$ \\
\hline $\mathrm{S}_{1}$ & 253 & 1585 & 720 & --- & --- & 1736 & --- & --- & 643 & 1093 \\
\hline $\mathrm{S}_{2}$ & 240 & 1586 & 719 & --- & --- & 1760 & --- & --- & 595 & 1051 \\
\hline $\mathrm{S}_{3}$ & 327 & 1576 & 729 & 3318 & 1671 & --- & --- & --- & 650 & 1074 \\
\hline $\mathrm{S}_{4}$ & 292 & 1482 & 703 & 3336 & 1663 & --- & --- & 1266 & 620 & 1046 \\
\hline $\mathrm{S}_{5}$ & 291 & 1540 & 737 & 3315 & --- & --- & 1635 & 1290 & 616 & 1080 \\
\hline $\mathrm{S}_{6}$ & 293 & 1576 & 714 & 3397 & 1655 & --- & 1655 & 1266 & 608 & 1043 \\
\hline $\mathrm{S}_{7}$ & 318 & 1543 & 658 & 3316 & 1605 & --- & 1601 & 1252 & 577 & 1061 \\
\hline $\mathrm{S}_{8}$ & 322 & 1480 & 746 & 3316 & --- & --- & 1605 & --- & 603 & 1105 \\
\hline $\mathrm{S}_{9}$ & 293 & 1541 & 694 & 3311 & 1606 & --- & 1616 & --- & 604 & 1079 \\
\hline $\mathrm{S}_{10}$ & 294 & 1575 & 711 & 3375 & 1605 & --- & 1604 & --- & 618 & 1067 \\
\hline
\end{tabular}

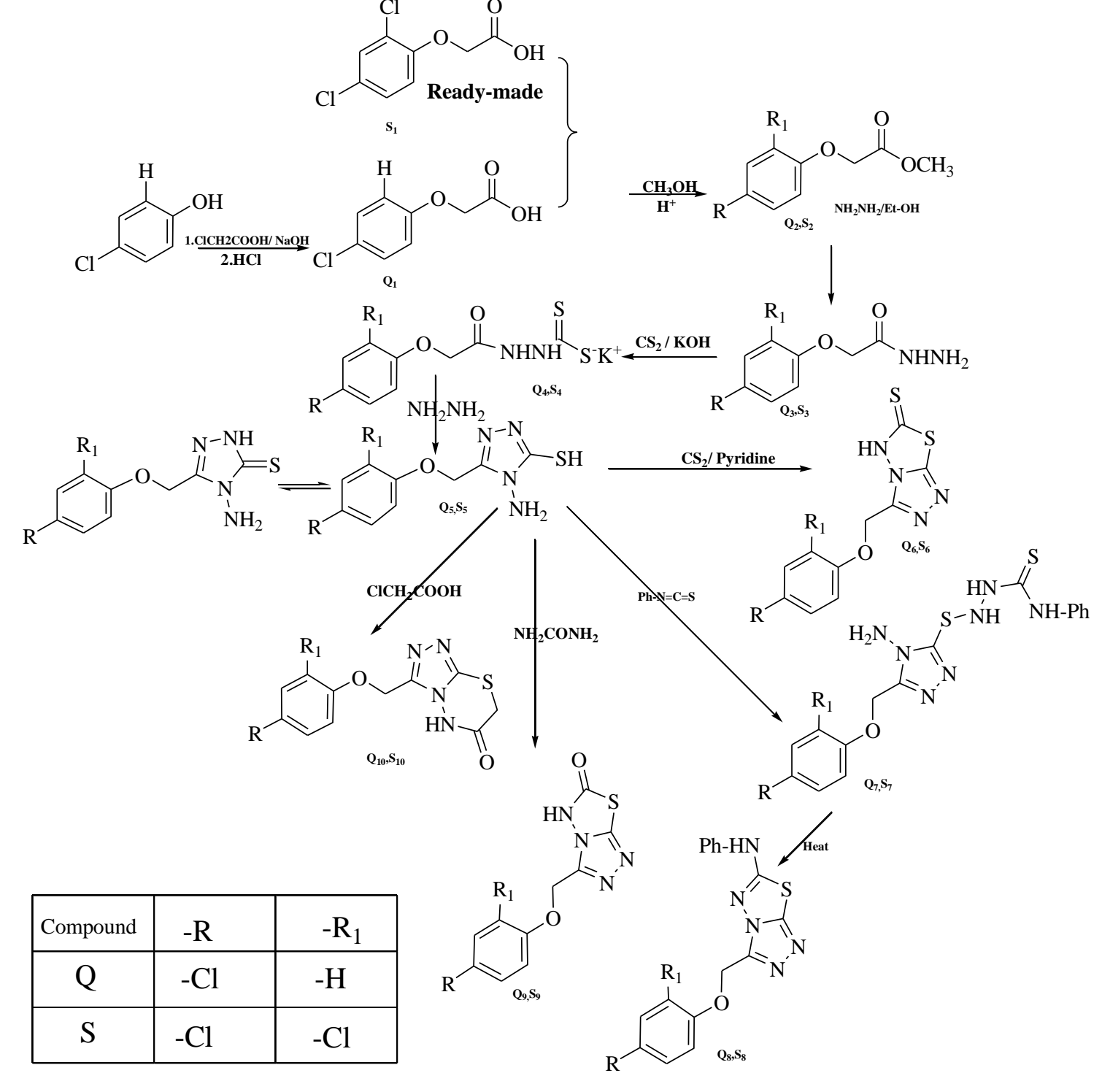

Scheme (1) 


\section{Results and Discussion:}

In this research the synthesis of new mono and bicyclic five membered ring heterocyclic compounds are reported. 4-Chlorophenol was treated with chloroacetic acid to give 4-chloro phenoxy acetic acid $\left(\mathrm{Q}_{1}\right)$ which when esterified with another phenoxy acetic acid (2,4-dichloro phenoxy acetic acid $\left.S_{1}\right)$ to gave methyl ester $\left(Q_{2}, S_{2}\right)$ by their reaction with absolute methanol in presence of sulfuric acid.

The ester then treated with hydrazine hydrate in ethanol to give the corresponding acid hydrazides $\left(\mathrm{Q}_{3}, \mathrm{~S}_{3}\right)$, the I.R spectrum of compounds $\left(\mathrm{Q}_{3}, \mathrm{~S}_{3}\right)$ show absorption at $1618-1671 \mathrm{~cm}^{-1}$ due to $(\mathrm{C}=\mathrm{O}$ amide). UV-Visible spectrum of $\left(\mathrm{Q}_{3}, \mathrm{~S}_{3}\right)$ show bands at $(227-285 \mathrm{~nm})$, The acid hydrazides were converted to 1,2,4-trazoles $\left(\mathrm{Q}_{5}, \mathrm{~S}_{5}\right)$ by their reaction carbon disulfide followed by hydrazine hydrate, the I.R spectrum for compounds $\left(\mathrm{Q}_{5}, \mathrm{~S}_{5}\right)$ showed absorption at 1604-1682 for (Q compounds), 1635$1667 \mathrm{~cm}^{-1}$ for ( $\mathrm{S}$ compounds) $(\mathrm{C}=\mathrm{N}), 1240-1252 \mathrm{~cm}^{-1}$ of (Q compounds) and $1252-1290 \mathrm{~cm}^{-1}$ of ( $\mathrm{S}$ compounds) $(\mathrm{C}=\mathrm{S})$. UV-Visible spectrum of $\left(\mathrm{Q}_{5}, \mathrm{~S}_{5}\right)$ show bands at $(292-294 \mathrm{~nm})$ for $(\mathrm{Q}$ and $\mathrm{S}$ compounds). Substituted 1,2,4-triazoles $\left(\mathrm{Q}_{5}, \mathrm{~S}_{5}\right)$ were treated with carbon disulfide in pyridine or with phenyl isothiocyanate to give triazole-thiadiazole fused ring systems $\left(\mathrm{Q}_{6}, \mathrm{~S}_{6}\right)$ and triazoles $\left(\mathrm{Q}_{7}, \mathrm{~S}_{7}\right)$ which on heating gave fused ring systems $\left(\mathrm{Q}_{8}, \mathrm{~S}_{8}\right)$ while the reaction of $\left(\mathrm{Q}_{5}, \mathrm{~S}_{5}\right)$ with urea or chloroacetic acid gave $\left(\mathrm{Q}_{9}, \mathrm{~S}_{9}\right)$ and $\left(\mathrm{Q}_{10}, \mathrm{~S}_{10}\right)$ respectively.

The I.R spectrum for compounds $\left(\mathrm{Q}_{6}, \mathrm{~S}_{6}\right) 1655-1660 \mathrm{~cm}^{-1}$ for $(\mathrm{C}=\mathrm{N})$ and $1242-1266 \mathrm{~cm}^{-1}$ for $(\mathrm{C}=\mathrm{S})$. UV-Visible spectrum of $\left(\mathrm{Q}_{6}, \mathrm{~S}_{6}\right)$ show bands at $(293-312 \mathrm{~nm})$, compounds $\left(\mathrm{Q}_{7}, \mathrm{~S}_{7}\right)$ 1601-1682 $\mathrm{cm}^{-1}(\mathrm{C}=\mathrm{N}), 1240-1252 \mathrm{~cm}^{-1}$ for $(\mathrm{C}=\mathrm{S})$. UV-Visible spectrum of $\left(\mathrm{Q}_{7}, \mathrm{~S}_{7}\right)$ show bands at $(299-318$ $\mathrm{nm})$.

Compounds $\left(\mathrm{Q}_{9}, \mathrm{~S}_{9}\right)$ show absorption at $1616-1618 \mathrm{~cm}^{-1}$ for $(\mathrm{C}=\mathrm{N})$. UV-Visible spectrum of $\left(\mathrm{Q}_{9}, \mathrm{~S}_{9}\right)$ show bands at $(293-317 \mathrm{~nm})$ and compounds $\left(\mathrm{Q}_{10}, \mathrm{~S}_{10}\right)$ showed absorption at $1604-1660 \mathrm{~cm}^{-1}$ for $(\mathrm{C}=\mathrm{N})$. UV-Visible spectrum of $\left(\mathrm{Q}_{10}, \mathrm{~S}_{10}\right)$ show bands at $(294-314 \mathrm{~nm})$, Tables (3 and 4). The physical data for the synthesized compounds showed on tables (1 and 2).

\section{References:}

1. K. Parmer, P. Sarju, Rinku, P. and P. Rikha, Res.J.Chem.Sci., 1(1),(2011)18-24.

2. K. V. Singh, M. K. Bhardwaj, V. K. Singh, and Savita, International Journal of Current Research in Applied Chemistry \& Chemical Engineering, 4, (2020) 41-45.

3. D.S. Bele and I. Singhvi, Asian Journal of Biochemical and Pharmaceutical Research, $1(2),(2011) 88-101$.

4. A.S. Geetha, R. Vijayaraj, T.R. Kumar and R.S. Anand, International Journal of Research in Pharmaceutical and Biomedical Sciences., 2(1),(2011)155-159.

5. N. Upmanyu, S. Kumar, M.D. Kharya, K. Shah, and P. Mishra, Acta Poloniae Pharmaceutica Drug Research., 68(2),(2011)213-221.

6. J.W .Dhore, G.B. Petha, S.P. Waghi, and G.D. Thorat, Scholar Research Library. 3 (1),(2011) 407-414. 
7. H. E. Hashem, A. E. E. Amr, E. S. Nossier, E. A. Elsayed and E. M. Azmy, Molecules 25 (2766), (2020), 1-18.

8. V.K. Tirlapur and T. Tadmalle, Der Pharmacia Sinica, 2 (1),(2011)135-141.

9. Z. M. Liu, Q. Chen, C.N. Chen, H.Y. Tu and G.F. Yang, Molecules, 13,(2008)1353-1360.

10. S. Jubie, P. Sikdar, S. Antony, R. Kalirajan, B. Goramma, S. Gomathy and K. Elango, Pak. J. Pharm. Sci., 24 (2),(2011) 109-112.

11. S. M. Gomha, H. M. Abdel-aziz, T. Z. Abolibda, S. A. Hassan and M. M. Abdalla, J. Heterocycl. Chem., (2020), 1-10.

12. A.S Geetha, R. Vijayaraj, T.R. Kumar, and R.S. Anand, International Journal of Research in Pharmaceutical and Biomedical Sciences, 2(1),(2011) 155-159.

13. A. A. Karigar, M. Himaja, M.V. Sunil, K.J. Parathap and S.S. Mukesha , IRJP, 2 (1), .(2011) 153158.

14. G. Mishra, A.K. Singh and K. Jyoti, Int. J. ChemTech Res.3 (3),(2011) 1380-1393.

15. A.A. Aly,* , A. A. Hassan, M. M. Makhlouf and S. Bräse, Molecules 25 (3036), (2020), 1-54.

16. T. Beresneva and E. Abele. Heterocyclic Letters, 1 (1),(2011) 73-78.

17. S. Valiulienẻ and A. Rutavičius. Chemija, 12 (1),(2001) 84-88.

18. Smith,T.V. and Waldron, N.M., "Vogel's Elementary Practical Organic Chemistry Preparation"3 ${ }^{\text {rd }}$ Ed., Longman group Ltd., London, p 316 (1980).

19. Al-naimi, K.H Yousif., Ph.D. Thesis, College of Education, University of Mosul (2000). (In Arabic).

20. Abdel-Aziz, H.A.; Elsaman, T.; Attia, M.I. and Alanazi, A.M., Molecules, 18, 2084-2095 (2013).

21. S. Hussain, Sharma, J. and M. Amir, E-Journal of Chemistry,5(4),(2008) 963-968.

22. K. A. Ali, J. Sharma and M. Amir, Acta Poloniae Pharmaceutica-Drug Research, 68(2),(2011) 237-247. 
23. G. Omprakash, Y. Anjaneyulu, N.S. Subramanian, M. Ramadevi, V.R.M. Gupta and G. Vijayalakshmi, RJPBCS, 2(1),(2011) 410-418. 